\title{
Removal of COD from Biodiesel Wastewater using a Hydrophobic Polymer
}

\author{
Elvis Fosso-Kankeu*, Marcelle Van den Berg, Frans Waanders and Sadanand Pandey
}

\begin{abstract}
Biodiesel production is increasing internationally as an alternative fuel. This is due to the rapid depletion of non-renewable energy sources. Pure biodiesel product can be obtained by washing the product with hot water. This results in a huge quantity of wastewater that is unsafe for disposal in normal drainage systems. Treatment of this wastewater is thus important for reuse or safe disposal in the environment. There are a lot of existing treatment methods, but they are costly, produce large quantities of excessive sludge and are not economically feasible. Flocculation is widely used in water treatment as it is easy to use and affordable. Flocculants can be synthesized to treat the specific wastewater type focusing on the reduction of certain impurities.

The reduction of Chemical Oxygen Demand (COD) in the biodiesel wastewater was investigated through jar-tests using hydrophobic, non-hydrophobic and a combination of hydrophobic and non-hydrophobic polymers that were synthesized.

Almost $68 \%$ COD removal was obtained with the non-hydrophobic polymer and about $56 \%$ COD removal was obtained with the hydrophobic polymer. The non-hydrophobic polymer has a better removal efficiency, as the wastewater contains a large quantity of hydrophilic organic matters. Although the hydrophobic polymer also removes COD, it could be seen that the hydrophobic polymer attracted the unreacted oil in the biodiesel wastewater.
\end{abstract}

Keywords - Biodiesel wastewater, hydrophobic polymer, non-hydrophobic polymer, COD, flocculation

Manuscript received September 25, 2018. This work was supported by the North-West University Potchefstroom Campus.

E. Fosso-Kankeu is with the with the Water Pollution Monitoring and Remediation Initiatives Research Group of the CoE in carbon-based fuels and the School of Chemical and Minerals Engineering at the North-West University, Potchefstroom, South Africa..

M. Van den Berg is with the with the Water Pollution Monitoring and Remediation Initiatives Research Group of the CoE in carbon-based fuels and the School of Chemical and Minerals Engineering at the North-West University, Potchefstroom, South Africa.

F.B. Waanders is with the Water Pollution Monitoring and Remediation Initiatives Research Group of the CoE in Carbon-based fuels and the School of Chemical and Minerals Engineering at the North-West University, Potchefstroom, South Africa.

S. Pandey is with the Water Pollution Monitoring and Remediation Initiatives Research Group of the CoE in carbon-based fuels and the School of Chemical and Minerals Engineering at the North-West University, Potchefstroom, South Africa.

\section{INTRODUCTION}

Biodiesel production is increasing internationally since fossil fuels are non-renewable energy sources which are depleting fast. Global warming and climate change are also affecting the environment in a negative way [1-11]. Biodiesel quality is dependent on its refinement process, which produces large volumes of wastewater which cannot be disposed of in normal drainage systems [12].

Biodiesel wastewater is produced after the washing phase and is a viscous fluid that is organic with a white colour. The effluent has high $\mathrm{pH}$ levels. The high $\mathrm{pH}$ levels are unfavourable for the growth of microorganisms, thus complicating the natural degradation of the oil in the wastewater [13]. Due to impurities in the biodiesel wastewater, the wastewater can be characterized by chemical oxygen demand and biological oxygen demand [12].

The wastewater effluent consists of water, residual biodiesel, soap, salts, methanol, un-reacted oil, and glycerol (main by-product) [1]. The discharge of such water in the environment will exacerbate the problem of water in a country considered as water scarce [14-24]

Flocculation is widely used in water treatment. Flocculation has advantages in treating wastewater containing oil, as it has no phase transition, operation is easy, affordable, and has an overall good treatment efficiency [25]. Flocculation is also convenient, environmentally friendly, easy to handle, and energy efficient [26-32].

Adding cationic polyacrylamide (CPAM) as polymer to the wastewater will affect the viscosity and permeability of the water by increasing and decreasing it respectively, which will result in a lower mobility ratio [33].

Hydrophobically associated polyacrylamide polymers (HAPAMs) have unique structures with thickening properties. HAPAMs have shear thinning abilities, anti-polyelectrolyte behaviour as a mobility control agent and with rheology modifiers [34]. Hydrophobic groups that are part of the polymer can enhance the interaction with hydrophobic oily colloids in the wastewater [25]. Hydrophobic monomers will temporary form intra- and intermolecular forces, minimizing their exposure to the water [33]. 


\section{MATERIALS AND METHODS}

\section{A. Materials}

Biodiesel was prepared with used cooking oil (UCO), methanol and potassium hydroxide $(\mathrm{KOH})$ as catalyst.

For the polymer synthesis, acrylamide (AM) was used as a base. Benzyldimethyl(2-hydroxyethyl) ammonium chloride (BMAC) was the monomer used to synthesize the hydrophobic polymer, and for the non-hydrophobic polymer [2-(Methacryloyloxy)ethyl] trimethyl ammonium chloride (MTAC) was used for synthesis. Both monomers were purchased from Rochelle Chemicals.

Potassium peroxodisulphate was added as initiator for the co-polymerization to take place. Hydrochloric acid $(\mathrm{HCl})$ and sodium hydroxide $(\mathrm{NaOH})$ were used for $\mathrm{pH}$ adjustment, and a combination of acetone and ethanol was used to wash the polymers.

\section{B. Biodiesel production and obtaining the biodiesel wash water}

A total of $4 \mathrm{~L}$ biodiesel was prepared in five batches. Each batch contained $800 \mathrm{~mL}$ UCO, $3.92 \mathrm{~g} \mathrm{KOH}$ and $160 \mathrm{~mL}$ methanol. The UCO was pre-heated to $55^{\circ} \mathrm{C}$ in a water bath. After the $\mathrm{KOH}$ was dissolved in the methanol, it was added to the $\mathrm{UCO}$ and continuously stirred for $1 \mathrm{~h}$ at $55^{\circ} \mathrm{C}$. After the $1 \mathrm{~h}$ reaction time the mixture was poured into a separation funnel to allow the complete separation of biodiesel from glycerol within $24 \mathrm{~h}$. After the glycerol was removed from the separation funnels, the remaining biodiesel was washed with deionised water. The water was heated to $40^{\circ} \mathrm{C}$ and added to the separation funnels. Each funnel was gently flipped for a couple of times, then returned to the stand to let the biodiesel separate from the water. The water, at the bottom of the funnel, was tapped into a plastic bottle, and the colour of the water was white. This washing process was repeated 5 times for each funnel. A total of 121 wash water was obtain

\section{Polymer synthesis}

A total of five polymers were synthesized, namely a hydrophobic polymer (HP 100\%), non-hydrophobic polymer (CP 100\%) and the other three polymers were a combination of the hydrophobic and non-hydrophobic polymers with $75 / 25 \%$, $50 / 50 \%$ and $25 / 75 \%$ ratios of the hydrophobic and non-hydrophobic monomers respectively.

$1 \mathrm{~g} \mathrm{AM}$ and $0.4 \mathrm{~g}$ monomer [BMAC/MTAC/combination] were dissolved in $20 \mathrm{~mL}$ of deionised water. The $\mathrm{pH}$ of this solution was adjusted to $4[ \pm 0.2]$ with $\mathrm{HCl}$ or $\mathrm{NaOH}$. A $1 \mathrm{M}$ solution both of $\mathrm{HCl}$ and $\mathrm{NaOH}$ was prepared and used for the synthesis process.

After the $\mathrm{pH}$ adjustment, the solution was purged with nitrogen gas for $15 \mathrm{~min}$. After $10 \mathrm{~min}$ of purging, the initiator (Potassium peroxodisulphate) was added. One $\mathrm{g}$ of initiator was dissolved with $3 \mathrm{~mL}$ of deionised water. For each polymer 100 $\mu l$ of the initiator mixture was added.

After completion of the purging, the solution was mixed using the Labcon $5082 \mathrm{U}$ shaking incubator at $60^{\circ} \mathrm{C}$ and $250 \mathrm{rpm}$ for $1 \mathrm{hr}$. The increase of solution density was observed overtime, confirming the formation of gel and therefore successful copolymerization taking place; the density of the gel varied depending of the ratios.

The polymers were washed with an ethanol-acetone mixture. The wash mixture was prepared in a 1:2 ratio, and the polymers were washed for $5 \mathrm{~min}$. When the wash mixture was added, one could see it becoming white as the unreacted reagents were washed from the polymer. It is important to let the solution settle before decanting the ethanol-acetone mixture containing unpolymerized monomers and homopolymers. The washed mixture settled on top of the polymer. The polymers were dried for 2 days in an oven at $60^{\circ} \mathrm{C}$.

\section{Flocculation tests}

For the flocculation tests $10,20,30,40$ and $50 \mathrm{mg} / \mathrm{L}$ dosages of flocculant were used to determine the COD and turbidity removal from the biodiesel wastewater.

Five beakers of $1 \mathrm{~L}$ volume each were used in which $200 \mathrm{ml}$ of wastewater was added. The different dosages of the flocculants were added. Flash mixing took place for $1 \mathrm{~min} 30 \mathrm{~s}$ at $200 \mathrm{rpm}$, followed by slow mixing for $15 \mathrm{~min}$ at $40 \mathrm{rpm}$. After the slow mixing, the beakers were left to settle for $30 \mathrm{~min}$. After the settling time, the $\mathrm{pH}$, turbidity and COD could be measured.

\section{E. Biodiesel wastewater and treated water parameter measurements}

The $\mathrm{pH}$ values were measured with a $\mathrm{pH}$ meter from Hanna Instruments. The $\mathrm{pH}$ electrode was placed in the water sample to record the $\mathrm{pH}$. After each $\mathrm{pH}$ measurement the electrode was washed with deionised water and dried.

Turbidity was measured with a HACH $2100 \mathrm{Q}$ turbidity meter. The turbidity meter has a glass vial that has a volume of $10 \mathrm{ml}$. This vial was filled with the water sample and inserted into the turbidity meter. The reading obtained was then noted as the sample's turbidity.

COD testing kits were ordered from Hanna Instruments. An aliquot of $0.2 \mathrm{~mL}$ of the water sample was added to the COD testing kit and digested at $150^{\circ} \mathrm{C}$ for 2 hours using a Hanna digester. The digested mixture was then left at room temperature to bring the temperature down at around $120^{\circ} \mathrm{C}$, and the tubes was inserted in the photometer for COD measurement. The photometer used was a HI 83099 COD and Multiparameter Photometer from Hanna Instruments.

\section{$F$. The characterization method of the polymers}

The hydrophobic, non-hydrophobic and combine polymers were characterized with FTIR and SEM techniques. The IRAffinity-1S Fourier transform infrared spectrophotometer from the University of Johannesburg was used with a spectral range of 4000 to $500 \mathrm{~cm}^{-1}$. The JEM-2100 multipurpose electron microscope (SEM) was used to determine the morphology of the polymers and the SEM image sizes ranged from 500 to $50 \mu \mathrm{m}$.

\section{RESULTS AND DisCUSSION}

\section{A. Morphology of polymers}

SEM images of the HP $100 \%$, CP $100 \%$, HCP $75 / 25 \%$, HCP 50/50\% and HCP 25/75\% are shown in Fig. 1. The morphology 
of the HP $100 \%$ is lumpy and has a homogeneous surface. CP $100 \%$ (Fig.1d) is smooth and has a homogenous surface. HCP 75/25\% (Fig.1c), HCP 50/50\% (Fig.1b) and HCP 25/75\% (Fig.1a) exhibit the properties of both the HP and CP polymers. Their morphology consists of a heterogenous and irregular surface. HCP $75 / 25 \%$ are more in sync with HP $100 \%$ and HCP $25 / 75 \%$ are closer to CP $100 \%$, which is due to the ratio's used in synthesis of the copolymers.

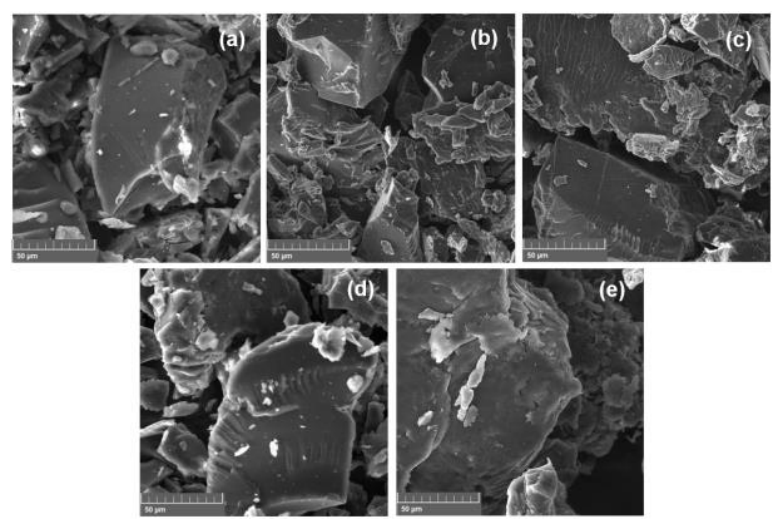

Fig. 1. SEM Images of synthesized polymers (a) HCP $25 / 75 \%$ (b) HCP $50 / 50 \%$ (c) HCP $75 / 25 \%$ (d) CP $100 \%$ (e) HP $100 \%$

\section{B. Binding groups of polymers}

FTIR spectroscopy was used to identify the binding groups on five synthesized polymers. Fig. 2 shows the spectrum of each of the five polymers. The acrylamide backbone could clearly be seen in all five polymers. Between the spectrum values of 3312.93 and $3174.68 \mathrm{~cm}^{-1}$ a N-H stretch exists, while a $\mathrm{C}-\mathrm{C}=\mathrm{C}$ symmetric stretch can be responsible of the peak between 1655.96 and $1603.17 \mathrm{~cm}^{-1}$. The backbone is completed with a $\mathrm{C}-\mathrm{C}$ stretch, C-N stretch and $=\mathrm{C}-\mathrm{H}$ bend in the ranges of $1448.02-1407.17 \mathrm{~cm}^{-1}, 1316.40-1049.08 \mathrm{~cm}^{-1}$ and $988.92-$ $719.30 \mathrm{~cm}^{-1}$ respectively.

An O-H stretch related to the peak between 3043.80 $2866.49 \mathrm{~cm}^{-1}$, can be found in the HP $100 \%$, HCP $75 / 25 \%$ and HCP $50 / 50 \%$ due to the alcohol group in the BMAC. The HCP 25/75\%, $\mathrm{HCP} 50 / 50 \%$ and $\mathrm{HCP} 75 / 25 \%$ contains a $\mathrm{C}=\mathrm{O}$ stretch and $\mathrm{C}-\mathrm{H}$ rock due to the combination of BMAC and MTAC with spectrum ranges of $1733.59-1729.91 \mathrm{~cm}^{-1}$ respectively. The CP $100 \%$ polymer contained a C-H stretch of $1454.35 \mathrm{~cm}^{-1}$ and a N-H bend of $2936.15 \mathrm{~cm}^{-1}$.

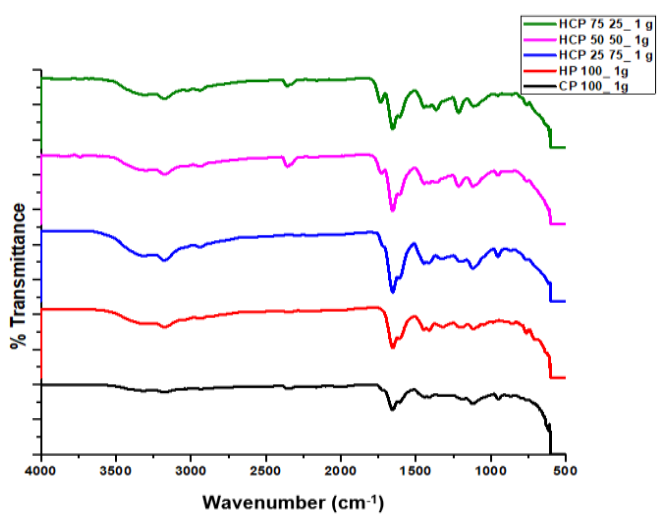

Fig. 2. FTIR result obtained and the comparison is shown of the different synthesized polymers used.

\section{Flocculation results}

The characterization done on the biodiesel wastewater showed a $\mathrm{pH}$ of 8.15 , turbidity of $728 \mathrm{NTU}$ and a COD measurement of $14370 \mathrm{mg} / \mathrm{l}$.

Tables 1 and 2 show the results obtained from flocculation of the HP 100\% and CP 100\% polymers respectively.

TABLE I: FLOCCULATION RESULTS FOR HP 100\%

\begin{tabular}{|l|l|l|l|l|l|}
\hline $\begin{array}{l}\text { Flocculant } \\
\text { dosages } \\
(\mathrm{mg} / \mathrm{l})\end{array}$ & $\mathrm{pH}$ & $\begin{array}{l}\text { Turbidity } \\
(\mathrm{NTU})\end{array}$ & $\begin{array}{l}\text { COD } \\
(\mathrm{mg} / \mathrm{l})\end{array}$ & $\begin{array}{l}\text { \% COD } \\
\text { removed }\end{array}$ & $\begin{array}{l}\text { \% Turbidity } \\
\text { removed }\end{array}$ \\
\hline 0.2 & 6.72 & 671 & 6850 & 52.33 & 7.83 \\
\hline 0.4 & 6.95 & 653 & 6666 & 53.61 & 10.30 \\
\hline 0.6 & 7.11 & 649 & 6490 & 54.84 & 10.85 \\
\hline 0.8 & 7.25 & 644 & 6440 & 55.18 & 11.54 \\
\hline 1 & 7.38 & 638 & 6380 & 55.60 & 12.36 \\
\hline
\end{tabular}

TABLE II: FLOCCULATION RESULTS FOR CP 100\%

\begin{tabular}{|l|l|l|l|l|l|}
\hline $\begin{array}{l}\text { Flocculant } \\
\text { dosages } \\
(\mathrm{mg} / \mathrm{l})\end{array}$ & $\mathrm{pH}$ & $\begin{array}{l}\text { Turbidity } \\
(\mathrm{NTU})\end{array}$ & $\begin{array}{l}\mathrm{COD} \\
(\mathrm{mg} / \mathrm{l})\end{array}$ & $\begin{array}{l}\text { \% COD } \\
\text { removed }\end{array}$ & $\begin{array}{l}\text { \% Turbidity } \\
\text { removed }\end{array}$ \\
\hline 0.2 & 5.23 & 604 & 5239 & 63.54 & 17.03 \\
\hline 0.4 & 5.84 & 596 & 5170 & 64.02 & 18.13 \\
\hline 0.6 & 5.97 & 590 & 5118 & 64.38 & 18.96 \\
\hline 0.8 & 6.09 & 562 & 4875 & 66.08 & 22.80 \\
\hline 1 & 6.31 & 537 & 4658 & 67.59 & 26.24 \\
\hline
\end{tabular}

With both polymers, the $\mathrm{pH}$ increased as the flocculant dosage was increased. CP $100 \%$ was more effective at removing COD from the biodiesel wastewater. Flocculation tests with the HP $100 \%$ polymer showed oily colloids clumping together on the surface of the water after treatment. HP 100\% removed both COD and turbidity, but the CP $100 \%$ had a better removal efficiency. One could say that HP 100\% focuses more on the oil in the wastewater, whereas $\mathrm{CP} 100 \%$ was better at removing the organics in the wastewater.

With the combination polymers, the results observed after the jar tests, indicate that there is an increase in COD removal as the ratio of the non-hydrophobic part in the different polymers increase. Fig. 3 and 4 show the impact of degree of hydrophobicity on the COD removal.

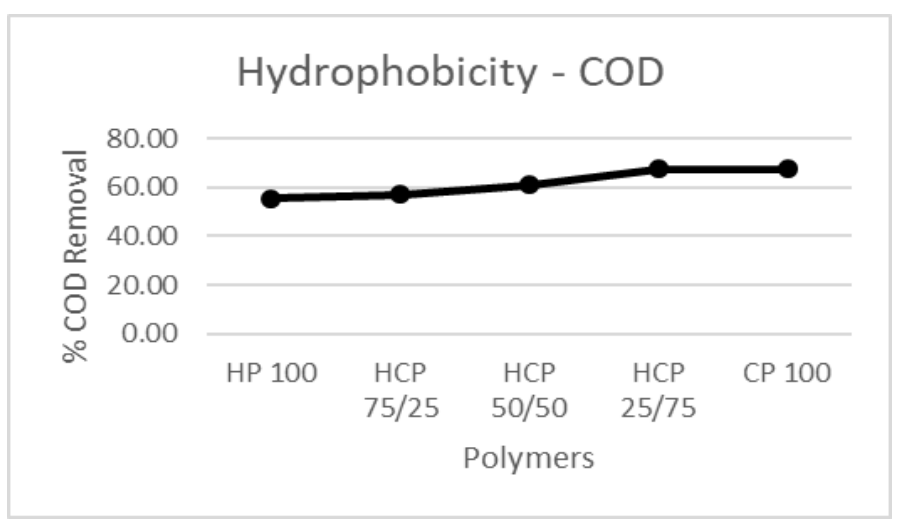

Fig. 3. COD results obtained for the hydrophobicity of the different polymers used 


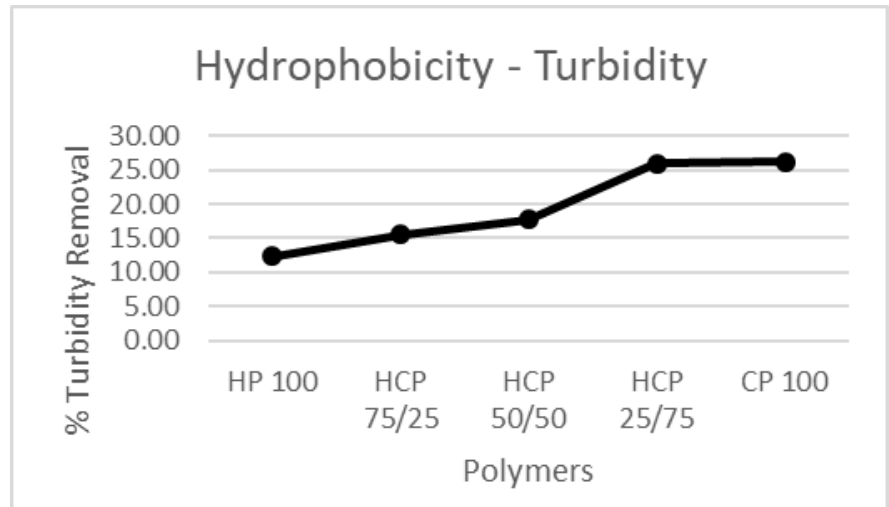

Fig. 4. Turbidity results obtained for the hydrophobicity of the different polymers used

\section{CONCLUSION}

In this study, five polymers including a hydrophobic, a non-hydrophobic and three intermediate polymers were synthesized using the sol-gel method. The characterization of these polymers using the FTIR analytical technique showed a variety of binding groups confirming the successful grafting of the initial ingredients. The synthesized polymers used as flocculants showed effective removal of COD from the biodiesel wastewater. After treatment of the biodiesel wastewater, the $\mathrm{pH}$ increased as the flocculant dosage increased. Turbidity decreased as well as the COD.

The hydrophobic polymer was found to react mostly with oil resulting in the formation of clumps at the surface of the water. This was not the case with the non-hydrophobic polymer. The non-hydrophobic polymer had better COD removal efficiency, implying that it reacted mostly with the hydrophilic organic matter in the wastewater.

\section{ACKNOWLEDGMENT}

The authors would like to thank the North-West University. M. van den Berg would like to thank Prof. Fosso-Kankeu, Prof. Waanders and Mr. Lemmer for their inputs, support and patience throughout the year.

\section{REFERENCES}

[1] Mozaffarikhah, K., Kargari, A., Tabatabaei, M., Ghanavati, H. \& Shirazi, M.M.A. 2017. Membrane treatment of biodiesel wash-water: A sustainable solution for water recycling in biodiesel production process. Journal of Water Process Engineering, 19:331-337. https://doi.org/10.1016/j.jwpe.2017.09.007

[2] E. Fosso-Kankeu, S. Marx, J.A. Ribberink, J.P.J. Van Den Bergh, Co-digestion of Sweet Sorghum Bagasse with Scientific and Crude Glycerols for Electricity Generation. $6^{\text {th }}$ International Conference on Green Technology, Renewable Energy and Environmental Engineering (ICGTREEE'2014). 27-28 November 2014, Cape Town-South Africa. (Award Winning Paper). Editors: Muzenda E. and Sandhu S. ISBN: 978-93-84468-08-8. Pp 265-270. 2014.

[3] E. Fosso-Kankeu, S. Marx, A. Meyer, Susceptibility of Saccharomyces cerevisiae to inhibitors and impact on bioethanol production yield. $6^{\text {th }}$ International Conference on Green Technology, Renewable Energy and Environmental Engineering (ICGTREEE'2014). 27-28 November 2014, Cape Town-South Africa. Editors: Muzenda E. and Sandhu S. ISBN: 978-93-84468-08-8. Pp 261-264. 2014.

[4] E. Fosso-Kankeu, S. Marx, A. Brink, Comparative adaptation of $B$. subtilis and $P$. aeruginosa in diesel supplemented medium and impact on biodegradation potential. $6^{\text {th }}$ International Conference on Green Technology, Renewable Energy and Environmental Engineering (ICGTREEE'2014). 27-28 November 2014, Cape Town-South Africa. Editors: Muzenda E. and Sandhu S. ISBN: 978-93-84468-08-8. Pp 253-256. 2014.

[5] E. Fosso-Kankeu, S. Marx, and C. Grobler, Simultaneous Gas and Electricity Production from an MFC Stimulated by Crude Glycerol. $7^{\text {th }}$ International Conference on Latest Trends in Engineering and Technology (ICLTET' 2015), November 26-27, 2015 Irene, Pretoria (South Africa). Editors: E. Muzenda and T Yingthawornsuk. ISBN: 978-93-84422-58-5. 2015.

[6] E. Fosso-Kankeu, S. Marx, and C. de Klerk, The Synergistic Inhibitory Effects of Weak Acids and a Phenol on the Growth of Saccharomyces Cerevisiae and Ethanol Yield. $7^{\text {th }}$ International Conference on Latest Trends in Engineering and Technology (ICLTET' 2015), November 26-27, 2015 Irene, Pretoria (South Africa). Editors: E. Muzenda and T Yingthawornsuk. ISBN: 978-93-84422-58-5. 2015.

[7] E. Fosso-Kankeu, S. Marx, F. Waanders and V. Jacobs, Impact of soil type on electricity generation from a Microbial Fuel Cell. $7^{\text {th }}$ International Conference on Latest Trends in Engineering and Technology (ICLTET' 2015), November 26-27, 2015 Irene, Pretoria (South Africa). Editors: E. Muzenda and T Yingthawornsuk. ISBN: 978-93-84422-58-5. 2015.

[8] E. Fosso-Kankeu, S. Marx, A. Meyer, Simulated inhibitory effects of typical byproducts of biomass pretreatment process on the viability of Saccharomyces cerevisiae and bioethanol production yield. African Journal of Biotechnology. Vol. 14, no. 30, pp. 2383-2394, 2015. https://doi.org/10.5897/AJB2015.14517

[9] E. Fosso-Kankeu, S. Marx, A. Brink, Adaptation behaviour of bacterial species and impact on the biodegradation of biodiesel-diesel. Brazilian Journal of Chemical Engineering. Vol. 34, no. 2, pp. 469-480, 2017. https://doi.org/10.1590/0104-6632.20170342s20150491

[10] C. de Klerk, E. Fosso-Kankeu, L. Du Plessis and S. Marx, Assessment of the viability of Saccharomyces cerevisiae in response to synergetic inhibition during bioethanol production. Current Sciences. 2018.

[11] Louis Christiaan Muller, Sanette Marx, Hermanus CM Vosloo, Elvis Fosso-Kankeu, Idan Chiyanzu. Rigid polyurethaned crude glycerol and technical lignins. Polymers from Renewable Resources. 1-22, 2018.

[12] Gonçalves, B., Borges Neto, W., Machado, A. \& Trovó, A. 2016. Biodiesel Wastewater Treatment by Coagulation-Flocculation: Evaluation and Optimization of Operational Parameters. Journal of the Brazilian Chemical Society. https://doi.org/10.21577/0103-5053.20160231

[13] A Daud, N.M., Sheikh Abdullah, S.R., Abu Hasan, H. \& Yaakob, Z. 2015a. Production of biodiesel and its wastewater treatment technologies: A review. Process Safety and Environmental Protection, 94:487-508.

https://doi.org/10.1016/j.psep.2014.10.009

[14] E. Fosso-Kankeu, F. Waanders, M. Reitz, Selective adsorption of heavy and light metals by natural zeolites. $6^{\text {th }}$ International Conference on Green Technology, Renewable Energy and Environmental Engineering (ICGTREEE'2014). 27-28 November 2014, Cape Town-South Africa. (Award Winning Paper). Editors: Muzenda E. and Sandhu S. ISBN: 978-93-84468-08-8. Pp 271-274. 2014.

[15] E. Fosso-Kankeu, F. Waanders, C. Fraser, Bentonite clay adsorption affinity for anionic and cationic dyes. $6^{\text {th }}$ International Conference on Green Technology, Renewable Energy and Environmental Engineering (ICGTREEE'2014). 27-28 November 2014, Cape Town-South Africa. Editors: Muzenda E. and Sandhu S. ISBN: 978-93-84468-08-8. Pp 257-260. Pp 257-260. 2014.

[16] E. Fosso-Kankeu, C.M. Van der Berg, F.B. Waanders, Physico-chemical activation of South African bentonite clay and impact on metal adsorption capacity. $6^{\text {th }}$ International Conference on Green Technology, Renewable Energy and Environmental Engineering (ICGTREEE'2014). 27-28 November 2014, Cape Town-South Africa. Editors: Muzenda E. and Sandhu S. ISBN: 978-93-84468-08-8. Pp 247-252. 2014.

[17] E. Fosso-Kankeu, A. Manyatshe, D. van der Berg, N. Lemmer, F. Waanders, and H. Tutu, Contaminants in Sediments across the Mooi and Vaal Rivers Network in The Vicinity of Potchefstroom. $7^{\text {th }}$ International Conference on Latest Trends in Engineering and Technology (ICLTET' 2015), November 26-27, 2015 Irene, Pretoria (South Africa). Editors: E. Muzenda and T Yingthawornsuk. ISBN: 978-93-84422-58-5. 2015. 
[18] E. Fosso-Kankeu, F. Waanders, and B. Steyn, Chitosan-graft-Polyacrylamide adsorbent for Sulphate removal from water. $7^{\text {th }}$ International Conference on Latest Trends in Engineering and Technology (ICLTET' 2015), November 26-27, 2015 Irene, Pretoria (South Africa). Editors: E. Muzenda and T Yingthawornsuk. ISBN: 978-93-84422-58-5. 2015.

[19] E. Fosso-Kankeu, F. Waanders, and C. Laurette Fourie, Surfactant Impregnated Bentonite Clay for the Adsorption of Anionic Dyes. $7^{\text {th }}$ International Conference on Latest Trends in Engineering and Technology (ICLTET' 2015), November 26-27, 2015 Irene, Pretoria (South Africa). Editors: E. Muzenda and T Yingthawornsuk. ISBN: 978-93-84422-58-5. 2015.

[20] E. Fosso-Kankeu, D.P. Van der Berg, F. Waanders, A. Manyatshe, N. Lemmer, and $\mathrm{H}$. Tutu, Mapping of surface water quality in the vicinity of Potchefstroom based on mining pollutants. $7^{\text {th }}$ International Conference on Latest Trends in Engineering and Technology (ICLTET' 2015), November 26-27, 2015 Irene, Pretoria (South Africa). Editors: E. Muzenda and T Yingthawornsuk. ISBN: 978-93-84422-58-5. 2015.

[21] E. Fosso-Kankeu, F.B. Waanders, F.W. Steyn, The Preparation and Characterization of Clay-Biochar Composites for the Removal of Metal Pollutants. $7^{\text {th }}$ International Conference on Latest Trends in Engineering and Technology (ICLTET' 2015), November 26-27, 2015 Irene, Pretoria (South Africa). Editors: E. Muzenda and T Yingthawornsuk. ISBN: 978-93-84422-58-5. 2015

[22] E. Fosso-Kankeu, F. Waanders, and M. Geldenhuys, Photocatalytic Degradation of Dyes using $\mathrm{TiO}_{2}$ Nanoparticles of Different Shapes. $7^{\text {th }}$ International Conference on Latest Trends in Engineering and Technology (ICLTET' 2015), November 26-27, 2015 Irene, Pretoria (South Africa). Award Winning Paper. Editors: E. Muzenda and T Yingthawornsuk. ISBN: 978-93-84422-58-5. 2015.

[23] E. Fosso-Kankeu, F. Waanders, E. Maloy, Copolymerization of ethyl acrylate onto guar gum for the adsorption of $\mathrm{Mg}$ (II) and $\mathrm{Ca}$ (II) ions. Desalination and Water Treatment. doi: 10.1080/19443994.2016.1165147: pp. 1-10, 2016.

[24] E. Fosso-Kankeu, C. van den Heever, G. Gericke, N. Lemmer, F. Waanders, Evaluation of the Performance of an Activated Carbon Supplemented Sand Filter for the Reduction of COD in Brewery Wastewater. $9^{\text {th }}$ Int'l Conference on Advances in Science, Engineering, Technology \& Waste Management (ASETWM-17). 27-28 November 2017, Parys, South Africa. Editors: F. Waanders, E. Fosso-Kankeu, B. Topcuoglu, M. Plaisent, Y. Thaweesak. ISBN: 978-81-934174-6-1. Pp. 24-29. 2017.

[25] A Zhao, C., Zheng, H., Gao, B., Liu, Y., Zhai, J., Zhang, S. \& Xu, B. 2018. Ultrasound-initiated synthesis of cationic polyacrylamide for oily wastewater treatment: Enhanced interaction between the flocculant and contaminants. Ultrason Sonochem, 42:31-41. https://doi.org/10.1016/j.ultsonch.2017.11.006

[26] Ma, J., Shi, J., Ding, L., Zhang, H., Zhou, S., Wang, Q., Fu, X., Jiang, L. $\& \mathrm{Fu}, \mathrm{K}$. 2018. Removal of emulsified oil from water using hydrophobic modified cationic polyacrylamide flocculants synthesized from low-pressure UV initiation. Separation and Purification Technology, 197:407-417.

https://doi.org/10.1016/j.seppur.2018.01.036

[27] E. Fosso-Kankeu, F. Waanders, Metal Ions Adsorption Affinity of Clay Materials from the North West Province of South Africa. An Interdisciplinary Response to Mine Water Challenges. International Mine Water Conference, August 2014 Xuzhou China. Editors, Sui, Sun \& Wang (Eds). 2014 China University of Mining andTechnology Press, Xuzhou, ISBN: 978-7-5646-2437-8. Pp374-378. 2014.

[28] I.O. Ntwampe, F.B. Waanders, E. Fosso-Kankeu, J.R. Bunt, Reaction dynamics of iron and aluminium salts dosage in AMD using shaking as an alternative technique in the destabilization-hydrolysis process. International Scientific Research Journal. Vol. 1, no. 8, pp. 5-23, 2015.

[29] E. Fosso-Kankeu; O. Ntwampe, F. Waanders, and A. Webster, The Performance of Polyaluminium Chloride and Bentonite clay Coagulant in the Removal of Cationic and Anionic Dyes. ${ }^{\text {th }}$ International Conference on Latest Trends in Engineering and Technology (ICLTET' 2015), November 26-27, 2015 Irene, Pretoria (South Africa). Editors: E. Muzenda and T Yingthawornsuk. ISBN: 978-93-84422-58-5. 2015.

[30] E. Fosso-Kankeu, H. Mittal, F. Waanders, I.O. Ntwampe, S.S. Ray, Preparation and characterization of gum karaya hydrogel nanocomposite flocculant for metal ions removal from mine effluents. International
Journal of Environmental Science and Technology. Vol. 13, pp. 711-724, 2016. https://doi.org/10.1007/s13762-015-0915-x

[31] E. Fosso-Kankeu, A. Webster, I.O. Ntwampe, F.B. Waanders, Coagulation/flocculation potential of polyaluminium chloride and bentonite clay tested in the removal of methyl red and crystal violet. Arabian Journal for Science and Engineering. DOI 10.1007/s13369-016-2244-x. 2016.

[32] E. Fosso-Kankeu, F. Waanders, A.F. Mulaba-Bafubiandi, A.K. Mishra. 2016. Flocculation performances of polymers and nanomaterials for the treatment of industrial wastewaters. In A.K. Mishra (ed). 2016. Smart Materials for Waste Water Applications. Wiley Scrivener. ISBN: 9781119041184. Pp 213 - 235.

[33] Viken, A.L., Spildo, K., Reichenbach-Klinke, R., Djurhuus, K. \& Skauge, T. 2017. Influence of Weak Hydrophobic Interactions on in Situ Viscosity of a Hydrophobically Modified Water-Soluble Polymer. Energy \& Fuels, 32(1):89-98. https://doi.org/10.1021/acs.energyfuels.7b02573

[34] El-hoshoudy, A.N., Desouky, S.E.M., Al-Sabagh, A.M., Betiha, M.A., M.Y, E.-k. \& Mahmoud, S. 2017. Evaluation of solution and rheological properties for hydrophobically associated polyacrylamide copolymer as a promised enhanced oil recovery candidate. Egyptian Journal of Petroleum, 26(3):779-785.

https://doi.org/10.1016/j.ejpe.2016.10.012

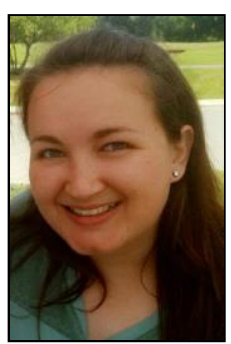

M. van den Berg was born and raised in a small town located in the Northern part of Kwa-Zulu Natal, Vryheid, South Africa. Marcelle is currently a final year student at the North-West University, studying chemical engineering.

She had opportunities through her years of study to learn project management skills through the opportunities the university gave her. She was fortunate to be part of the start of a small-scale biodiesel production plant situated in Benoni. Her love for water treatment started in 2016 after finishing vacation work at a water treatment consultation company. 